\title{
An investigation into the relationship between customer relationship marketing and customer retention: superstore retailing context in Bangladesh
}

\author{
Palto Datta \\ Centre for Innovative Leadership Navigation, UK \\ Peter Fraser \\ Mohamed Lebcir \\ University of Hertfordshire, UK
}

\begin{abstract}
Keywords
Customer Relationship Marketing, Customer Retention, Customer Loyalty, Relationship quality, Service quality
\end{abstract}

\begin{abstract}
The context of this study is Bangladesh s food retailing sector. The main purpose of this study is to investigate the relationship between Customer Relationship Marketing (CRM) and customer retention. The core aim of Relationship Marketing is to build long lasting mutually bonded relationships with customers and various other important stakeholders. The concept has attracted considerable attention among scholars in recent decades and has appeared in service marketing literature as a new marketing paradigm. The concept is critical to the success of any organisation as it has been an accepted phenomenon that maintains that existing customers are far easier to retain than is the process of acquiring new customers. In order to stay in business and cope with the challenging business dynamism, organisations are continuously searching for reliable and serviceable strategies to be employed in order to increase customer retention.

However, there is a lack of consensus among researchers on the core antecedents of relationship marketing that can be used to achieve the above aims, especially while the concept is new in the context of organised retailing sectors in Bangladesh. In response, the study developed a conceptual framework of customer retention strategy which incorporates bonds, service quality and relational quality into one relationship model. The model establishes eleven hypotheses. A sample of 202 grocery food retail customers were selected in a random sample from four selected superstores. The results support hypothesized relationships built on the model. The findings indicate that service quality, trust, bond and customer satisfactions are vital for creating positive customer loyalty which in turn creates customer retention.
\end{abstract}

Corresponding author: Palto Datta

Email addresses for corresponding author: paltodatta@yahoo.co.uk

First submission received: $10^{\text {th }}$ August 2017

Revised submission received: 24 $4^{\text {th }}$ May 2018

Accepted: 9th July 2018

\section{Introduction}

The food retail industry is both very dynamic and vast; it has been undergoing rapid changes throughout the world over the past few decades. Both in North America and Europe, consumers have witnessed the emergence of supermarkets, hypermarkets and mega supermarkets as the dominant retail form. The main reasons for this that the large retailers have developed a new form of shopping experience by introducing self-service and best service quality provisions to the customers, subsequently, customers have readily embraced such new high street phenomenon with enthusiasm. Since then steadily the whole landscape of food retailing has been changed. Customers are looking for better quality products with better price, in essence a good value for money offering. Convenient payment methods, varieties of branded products, parking facilities, convenient locations and other service and product related factors all have contributed to the changes of consumer behaviours. Additional factors such as the growth of car ownership among middle class with greater financial freedom and stable employment have also 
contributed to their growth. To fulfil consumer demands and expectations food retailers are continuously shaping their business model and the services and products that they offer.

Many customer-oriented factors are associated with the contemporary challenges in the area of grocery food retailing in Bangladesh. Some of these factors are economic fluctuations, changes in consumers' lifestyle, demographic characteristics,eating habits, more conducive shopping behaviour, access to a wide range of better quality imported and branded products, rapid growth of urbanisation, an expanding middle class with greater car ownership and higher disposable incomes. Individual attitudes towards shopping behaviour are also affected by various social factors surrounding the consumers (Ragayogan \& Muthumani, 2015). These changes will continue to increase in future and influence the grocery food retailing sector. Therefore, it is very important for the retailers to build and maintain a loyal customer base and increase customer retention to sustain competitive advantage.

\section{Literature Review \\ 2.1 Relationship Marketing}

Over the past years organisations have been changing dramatically to cope with the challenges they are facing continuously due to technological advancement, changes of external global environmental forces, changing behavious of unpreditacble consumers, changing their shopping and consumption patterns. To cope with these contemporary challenges and complexities organisations are continuously seeking to adopt new strategies and practices. More and more customer oriented policies are taken on board by management to survive and achieve competitive advantage and of course to maximise profits. One of such customer oriented philosophy is Customer Relationship Marketing (CRM).

The actual concept of CRM evolved into the mainstream marketing and business literature during the mid-20 $0^{\text {th }}$ century (Datta, Omar \& Dixon, 2011). McGarry (1951) is one of the first who used and discussed the concept of contractual relationships of marketing; He argued that marketing cost can be reduced by $10-20 \%$ by developing and maintaining long lasting mutual and continuous dynamic relationships between organisations and customers. However, Berry (1983) is the first pioneer scholar who used relationship marketing in service literature and has been identified by various scholars in most of the service marketing literature (Ndubisi, 2007; Myhal, Kang \& Murphy, 2008; Julian, Ahmed, Wei \& Bojei, 2016). Since then, the concept has evolved in an evolutionary way in order to respond to various external environmental factors and the changing nature of consumer's demands. Various theories, concepts and models of Relationship Marketing have been developed in different parts of the world, although, most of them are in developed countries in which the service sector is prominent or in rise. Berry (1983) considered Relationship Marketing as the most important strategy for building, maintaining and enhancing relationships with customers. Morgan and Hunt (1994) asserted that relationship marketing is vital to building and managing successful rapport with various stakeholders. This idea is also supported by Gilaninia; Almani; Pournaserani \& Mousavian (2011).

\subsection{Customer Retention}

There are numerous studies in the marketing literature especially service literature on customer retention and its various antecedents, (Sheth, 1992; Ranaweera \& Neely, 2003; Gustafsson, Johnson \& Roos, 2005; Myhal; Kang, J \& Murphy, 2008; Moeller; Fassnacht \& Ettinger, 2009; Rajayogon,. \& Muthumani, 2015; Julian; Ahmed; Wei \& Bojei, 2016). Early research on service quality had a simple premise that satisfied customers are more committed thus continues service patronage and in return more financial benefits for the organisation. However, it is now evident that mere satisfaction is not the only determinant factors of customer patronage behaviour and there are other factors are associated with customer retention. Therefore, contemporary service researchers focus more on drivers of the customer behaviour than the drivers of customer satisfaction (Ranaweera \& Neely, 2003).

The prime goals of relationship marketing are (1) customer retention (Gronroos, 1994), (2) maximise profitable relationship with customers by increasing the value of the relationship (Ghahfarokhi \& Zakaria, 2009) and (3) focusing on customer retention which yields several economic benefits (Dawkins \& Reichheld, 1990). Organisational performance can be improved by attracting and retaining satisfied customers (Julian et al, 2016). A study conducted by Reichheld \& Sasser (1990) also assessed the importance of customer retention. The results of their study indicate that organisational profits in service 
sectors greatly influenced by the length of the customer relationship. Even some cases less satisfied customers tend to stay with the store, means more economic benefits for the organisation. Therefore, customer retention is vital for the organisation as it can cost at least five times more to attract a new customer than keeping an existing one (Weinstein et al., 1996

\section{Conceptual framework and research hypotheses \\ 3.1 Consequences of Relational Bonds}

Organisations in current competitive markets are searching for effective strategies to employ to increase customer retention; researchers are investigating and developing meaningful models, theories and strategies. Relational bonds become a powerful strategy for service providers to create long-term buyer-sellers' relationships (Wilson, 1995). Relationship bonds have been identified as one of the major components in long lasting buyer seller relationships (Wang; Liang \& Wu, 2006, Gonu \& Boohene, 2016)). In service marketing literature there are many categories of relationship bonds that have been found, Scholars have identified three main bonds that have profound effects on relationship development; these are financial bonds, social bonds and structural bonds. Wang; Liang \& Wu (2006) found that both structural and social bonds have profound effects on high involvement products, while financial bonds are important for low involvement products.

\subsubsection{Bonds and Relationship Quality: Trust, Commitment \& Satisfaction}

Relational bonds are pivotal to create long lasting buyer seller relationships and to foster customer loyalty. Coulter \& Ligas (2004) pointed out that customers do not only receive financial benefits from a service provider, but also expect to receive relational and social benefits. Social bonds are important antecedents of trust in the service encounter (Morgan \& Hunt, 1994) and trust is intrinsic in relationship building. Many previous studies highlighted the importance of bonds to overall organisational performance by enhancing customer satisfaction, trust and commitment (Wang et al, 2006; Cater \& Cater, 2009; Chen \& Chiu, 2009; Huang; Fang; Huang; Chang \& Fang, 2014; Julian et al, 2016). Various literatures suggest the importance of bonds in creating trust in relationships between buyerssellers. Carter (2008) proposed that social bonds positively influence trust.

To create long term customer relationship, commitment is vital. According to Morgan and Hunt (1994) for the creation of the most successful relationship marketing, the existence of trust and commitment is of paramount importance. Berry and Parasuraman (1991) also asserted that mutual commitment is the foundation for building relationships and there is no cemented rapport without any commitment. In Indian context study conducted by Dash et al (2007) found that social bonding and commitment is positively associated and in collectivistic society the effect of bonding on commitment is higher than in individualistic culture. An empirical study conducted by Ziaullah et al (2014) in Chinese eretailing context found that bonds has significant effect on customer commitment.

Bonds can have a profound effect in influencing customer satisfaction and building long lasting relationships between organisations and customers (Cann \& Sumrall, 1997). An empirical study conducted by Chen \& Chiu (2009) in Chines e-retailing context. Their study indicates that customer satisfaction is directly influenced by financial bonds.

Based on the above discussion it can be agreed that bonds have a direct positive effect on customer Trust, Commitment \& Satisfaction. The following hypotheses are developed:

H1: $\quad$ As bond strength rises in relationship, customer trust rises simultaneously

H2: $\quad$ As bond strength rises in relationship, customer commitment rises simultaneously

H3: As bond strength rises in relationship, customer satisfaction rises simultaneously

\subsection{Consequences of Service quality}

For building a successful customer relationship, the concept of service quality has been considered as one of the key constructs (Wong \& Sohal, 2006; Adoyo; Charles; Patrick; Beatrice; Frederick \& Samson, 2012), The concept has become one of the most and powerful competitive weapons as a discussed topic in marketing literatures (Clottey; Collier \& Stodnick, 2008; Grewal; Levy \& Kumar, 2009). In long-term buyer seller relationships various dimensions of service quality can influence the consumer repurchase intentions. Therefore, it is of paramount importance for service providers to understand the 
service quality dimensions and deliver the best quality to their customers, which in turn increases customer satisfaction and customer loyalty.

Wong and Sohal (2006) posit that trust is directly influenced by service quality. An empirical study conducted by Chiou \& Droge (2006) also identified service quality as a predictable factor of customer overall satisfaction and directly associated with trust. According to Doney \& Cannon (1997) there are consumers who evaluate service providers in order to gain trust and they use various explicit and implicit cues, quality is one of the most important cues. Wong \& Sohal (2006) proposed that various factors of service quality such as respect to customers, sales personnel knowledge in relation to customer enquiry, and capability to handle customer`s complaints have a direct relationship in building higher level of trust.

Therefore, the researcher acknowledges the relationship between service quality and relational quality dimensions (i.e Trust and satisfaction) and hence, the following two hypotheses:

H4: As service quality strength rises, customer trust rises simultaneously

H5: As service quality strength rises, customer satisfaction rises simultaneously

\subsection{Trust and commitment}

According to Morgan \& Hunt (1994) to build successful relationships, the existence of trust and commitment is important. A study conducted by Adoyo (2012) on interrelationship between relationship quality and customer loyalty found that trust and commitment is positively correlated. They further asserted that strong customer trust to a service provider ensures commitment to the relationships. Various antecedents of trust such as the service provider`s ability and reliability, benevolence, credibility, integrity and predictability are important for building trust which ultimately leads to higher commitment. This phenomenon was also found in other substantial studies (Caceres \& Paparoidamis, 2007; Sohail, 2012; Boora \& Singh, 2011).

Thus, next hypothesis is developed to establish the relationships between trust and commitment.

H6: As trust strength rises, customer commitment rises simultaneously

\subsection{Customer satisfaction and commitment}

Various studies indicate that customer`s relative attitude and satisfaction are influenced by service quality. In general, satisfied customers are more committed to a specific store and such customers are always loyal and happy to recommend to their friends and relatives (Heskett, 2002). Hennig-Thurau; Gwinner \& Gremler (2002) stated that customer satisfaction has direct impact on customer commitment as high levels of customer satisfaction influences customer repeat purchase behaviour. In relationship marketing literature satisfaction has been conceptualised as key variable of relationship quality (Caceres \& Paparoidamis, 2007) and Service personnel friendliness \& knowledge of the customer are most important determinants of customer satisfaction (Shamadasani \& Balakrishan, 2000). Other studies also found positive influence of customer satisfaction on customer commitment (Boora \& Singh, 2011; Adoyo et al, 2012).

\section{H7: As customer satisfaction strength rises, customer commitment towards the store rises simultaneously}

\subsection{Consequences of relationship quality}

Palmatier; Dant; Grewal \& Evans (2006) argue the main purpose of adopting relationship marketing is to gain and increase customer loyalty. Various studies identified trust, commitment and satisfaction are the main predictor construct of customer loyalty (Wang et al, 2006, Palmatier; Dant., Grewal \& Evans, 2006; Mosahab; Mahamad \& Ramayah, 2010; Boora \& Singh, 2011; Adoyo et al, 2012). Hennig-Thurau; Gwinner, K.P. and Gremler (2002) regarded relationship quality as a meta-construct comprising of three core interrelated variables of trust, commitment and satisfaction. Hennig-Thurau et al (2002) further suggested that customer loyalty is directly influenced by trust and commitment and the level of customer loyalty will be higher when the customer has a positive perception of trust. Bitner (1990) viewed customer satisfaction as the most important antecedent of customer loyalty, which support the view of Cronin and Taylor (1992). There are numerous studies indicate the positive relationships between satisfaction and loyalty (Hennig-Thurau et al, 2002). Many previous studies on relationship quality 
indicate that one of the most important determinants of customer loyalty is quality of relationship (Leverin \& Liljander, 2006; Kunal \& Khan 2013). Auruskeviciene; Salciuviene \& Skudiene (2010) also found strong evidence in their study that trust influences customer loyalty. Based on the above discussion the following three hypotheses are developed:

H8: As trust strength rises, customer loyalty rises simultaneously

H9: As customer commitment strength rises, customer loyalty rises simultaneously

H10: As customer satisfaction strength rises, customer loyalty rises simultaneously

\subsection{Customer loyalty and retention}

In relationship marketing literature, customer retention has been conceptualised as multidimensional constructs consisting of both attitudinal and behavioural construct (Ennew \& Binks, 1996) and loyalty has been core antecedent of customer retention. To stress the importance of customer loyalty, Bansal and Gupta, (2001) posit that customer loyalty is not a choice but the only way of building sustainable competitive strategy. Food retailers must establish and manage a group of loyal customers for the organisational survival in intense competitive market environment (Huddleston; Whipple \& VanAuken, 2004). This supports the findings of Ndubisi \& Chan (2005) who suggested that the organisation must turn its ordinary customers into loyal ones. Various studies suggest that customer loyalty is seen as an important relationship outcome, which leads to customer retention (Dick \& Basu, 1994; Ennew \& Binks, 1996, Huddleston; Whipple \& VanAuken, 2004).

H11: As customer loyalty strength rises, customer retention rises simultaneously

\section{Proposed conceptual framework of Customer Retention Strategy}

The conceptual model integrates the concept of bonds, service quality and components of relational quality (Trust, commitment and satisfaction) into one relationship model to show the relationship between these five constructs and customer loyalty \& customer retention.

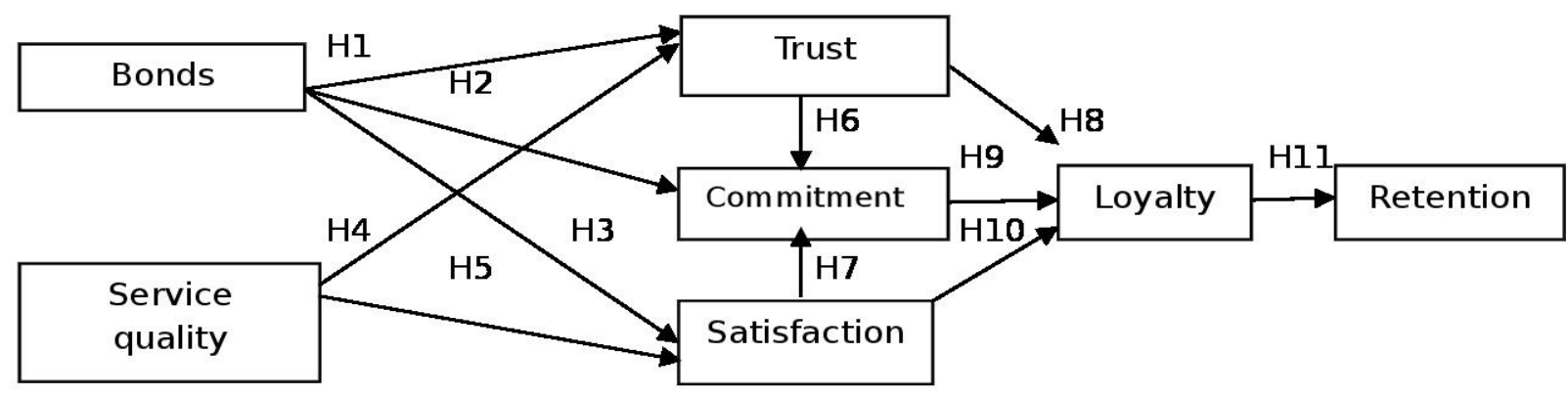

Figure-1: Proposed conceptual framework of customer retention strategy (CRS)

The proposed conceptual framework of customer retention strategy shown in above figure, establishes 11 hypotheses. Hypotheses H1, H2 \& H3 link to bonds and relational quality elements comprising trust, commitment and satisfaction. Hypotheses $\mathrm{H} 4$ \& $\mathrm{H} 5$ are linked to service quality and two major components of relational quality (trust and satisfaction). Relational bonds in this study is seen as composite measures comprising social bonds, financial bonds and structural bonds. Bonds and service quality are the first steps for the service provider to create customer trust, commitment and satisfaction while customers use them as a precondition to evaluate the service provider's service provision for the shopping decision to be taken. Therefore, these two-variable seen as exogenous constructs in this study as they build the foundation for a long-term buyer seller relationship.

In terms of relational quality, three variables are found to be more common and have interconnectedness to create stronger relational outcome, which is in this case loyalty. These variables are: trust, commitment and satisfaction. These variables are treated individually in this study and the relational variables plus loyalty and retention, treated as endogenous constructs. However, retention is an independent variable in this study, which has backward linkages with other exogenous and endogenous constructs. Therefore, within the relational quality two further hypotheses were developed which show the relationship between trust and commitment (H6) and satisfaction and commitment (H7). Once the 
relational quality achieved and combined the relational outcome to be found strong. Hence, the individual effect of relational quality construct on customer loyalty justified with the further three hypotheses of $\mathrm{H} 8$ (trust and loyalty), H9 (commitment and Loyalty) and H10 (satisfaction and loyalty). The final hypothesis shows the association between loyalty and retention (H11). Bonds and service quality provision are very important for the both customers and service providers to create long term buyer-seller relationships.

\section{Research methodology}

The study used four (4) leading organised grocery superstores in Bangladesh. These are: Agora, Meenabazar, Nandan and Shapna. The criteria used to select these stores chains were: sales volume, market share of the store, status of the ownership and period of operation. To operationalise various constructs A 5 (Five) point Likert-type scale was used and various items were selected from previously tested scale to measure various constructs. Many previous studies adopted this type of instruments and widely used as most effective research instruments in the study of consumer's behaviour (e.g. Bloemer, Ruyter \& Wetzel, 1999; Kim \& Jin, 2001; Leng \& Botelho, 2011, Yang et al, 2014).

Data were collected through mail questionnaires by using self-administered questionnaires, personally handed to the respondent at the doors and car parks of four large supermarkets. Four shopping areas were in Dhaka (the capital city) in four different locations. Dhaka has been chosen as a sample location for this study, because: (i) Dhaka is the capital city of Bangladesh with more than 16 million people; (ii) These are the prime areas with high socio-economic groups. These areas are mainly residential areas with multiple shopping malls; (iii) 95\% of the superstores are in Dhaka

The final questionnaires were given out to 1400 household and only $38 \%$ had responded to the questionnaires, which give a sample size of 532. However, only $202(38 \%)$ of them was useable. It is logical that the larger the size of the sample, the greater is the precision or reliability when research is replicated (Saunders; Lewis \& Thornhill, 2007). The sample size was found to be representative for the store population. A study conducted by Bloemer \& Ruyter (1998) in a major Swiss city in the German-speaking part of Switzerland used only 153.

\section{Research findings}

\subsection{Characteristics of study sample}

The study included $\mathrm{N}=202$ subjects, with a statistically equal [Chi ${ }^{2}($ one, $\left.N=199)=.41 ; p=.523\right]$ gender distribution: 104 males (percentage $=52.3$ ) and 95 females (percentage $=47.7$ ). 25-34 was the largest age group $(N=98 ; \%=48.5)$, age group 35-44 was lower $(N=52 ; \%=25.7)$ and the smallest groups were 16-24 $(\mathrm{N}=33 ; \%=16.3), 45-54(\mathrm{~N}=16, \%=7.9)$, and 55 and over $(\mathrm{n}=3, \%=1.5)$. Most of the respondents were married, employed, postgraduate or undergraduate; lived in a four-person household, with three or four rooms. To simplify the description of the sample and for convenience detailed data is summarized in the below table:

Table 1: Demographic profile of sampled respondents

\begin{tabular}{|l|l|l|l|}
\hline Measure & Items & Frequency & Percentage (\%) \\
\hline \multirow{5}{*}{ Gender } & Male & 104 & 51.0 \\
\cline { 2 - 4 } & Female & 95 & 46.6 \\
\hline \multirow{5}{*}{ Age Group } & $16-24$ & 33 & 16.2 \\
\cline { 2 - 4 } & $25-34$ & 98 & 48.0 \\
\cline { 2 - 4 } & $35-44$ & 52 & 25.5 \\
\cline { 2 - 4 } & $45-54$ & 16 & 7.8 \\
\cline { 2 - 4 } & $55+$ & 3 & 1.5 \\
\hline \multirow{5}{*}{ Income } & Single & 72 & 35.3 \\
\cline { 2 - 4 } & Married & 105 & 51.5 \\
\cline { 2 - 4 } & Divorced & 12 & 5.9 \\
\cline { 2 - 4 } & Widowed & 4 & 2.0 \\
\cline { 2 - 4 } & Co-habiting & 4 & 2.0 \\
\hline & $10,000-20,000$ & 22 & 18.1 \\
\cline { 2 - 4 } & $20,000-30,000$ & 37 & 31.4 \\
\cline { 2 - 4 } & $30,000-40,000$ & 64 & 34.3 \\
\cline { 2 - 4 } & $40,000-+$ & 70 & \\
\hline
\end{tabular}

www.jbrmr.com A Journal of the Academy of Business and Retail Management (ABRM) 


\begin{tabular}{|c|c|c|c|}
\hline \multirow{6}{*}{ Education } & Post-graduate & 75 & 36.8 \\
\hline & Undergraduate & 91 & 44.6 \\
\hline & Higher secondary level & 31 & 15.2 \\
\hline & Secondary level & 3 & 1.5 \\
\hline & Primary level & 2 & 1.0 \\
\hline & No education & 0 & 0.0 \\
\hline \multirow{7}{*}{$\begin{array}{l}\text { Number of People in a } \\
\text { Household }\end{array}$} & 1 & 9 & 4.4 \\
\hline & 2 & 23 & 11.3 \\
\hline & 3 & 34 & 16.7 \\
\hline & 4 & 74 & 36.3 \\
\hline & 5 & 48 & 23.5 \\
\hline & 6 & 6 & 2.9 \\
\hline & $7+$ & 8 & 3.9 \\
\hline \multirow{6}{*}{ Occupation } & Student & 53 & 26.0 \\
\hline & Employed & 72 & 35.3 \\
\hline & Self-employed & 35 & 17.2 \\
\hline & Housewife & 36 & 17.6 \\
\hline & Retired & 3 & 1.5 \\
\hline & Unemployed & 2 & 1.0 \\
\hline \multirow[t]{6}{*}{ Number of rooms available } & Single room & 9 & 4.4 \\
\hline & 2 rooms & 29 & 14.2 \\
\hline & 3 rooms & 71 & 34.8 \\
\hline & 4 rooms & 57 & 29.9 \\
\hline & 5 rooms & 24 & 11.8 \\
\hline & $6+$ rooms & 11 & 5.4 \\
\hline
\end{tabular}

\subsection{Research factors evaluation}

Before performing any analysis, a three-stage complex analysis model was used to check the consistency and compliance of subject's responses. Firstly, it has been rated correlations between items forming scales. Then, in order to determine the level of reliability of the questionnaire (understood as a feature of the reliability measurement accuracy), Cronbach's alpha statistics for a single construct was calculated. Finally, a series of factor analyses were used, which measures of variance explained and KMO coefficient could assess the quality of a single scale in the sense of a single theoretical construct. All analyses showed that between those selected to specific scales items of the questionnaire are those that do not fit into the theoretical concept. This showed low values of correlation coefficients, low values of antiimage correlations and Cronbach's alpha sub-indices (exclusion indices). These items factor analysis was also indicated as separate concepts in the eyes of the respondents (more factors numbers). The results of these preliminary analyses are shown in the tables below, where for each scale the number of initial items is given, a list of items from the survey used, reliability, KMO coefficient and a received number of factors after single PCA (Principal Component Analysis) analysis for construct. The first table shows coefficients for the original (assumed) constructs, in the second table are coefficients for factors cleaned.

Table 2: Pre-factors description (before clearing data/items)

\begin{tabular}{llllll}
\hline Scale & Item Number & Items & Alpha & KMO & Factor Number \\
\hline \hline Quality & 20 & $9-28$ & .755 & .865 & 4 \\
Trust & 3 & $29-31$ & .639 & .622 & 1 \\
Commitment & 6 & $32-34,47-48$ & .643 & .681 & 2 \\
Bonds & 5 & $36-40$ & .737 & .765 & 1 \\
Satisfaction & 2 & $44-45$ & .678 & .500 & 1 \\
Loyalty & 7 & $46,49-52$ & .648 & .636 & 3 \\
Retention & 3 & $58-60$ & .707 & .668 & 1 \\
\hline \hline
\end{tabular}


In a series of combined analysis that were excluded are indicated in the following table items that distort the measured values of factors, making it possible to consider them as particularly strong, so we can talk about their correctness: factors have been "purified" from external "disturbances", and are already single metrics with meaningful properties. Additional information about cleared factors is the fact that the correlation coefficients improved, and we can even talk about improving the overall (theoretical) factors with practical data. The table also noted that items have been finally removed from the research factors.

Table -3: Post-factors description (after clearing data/items)

\begin{tabular}{lllllll}
\hline \hline Scale & $\begin{array}{l}\text { Item } \\
\text { numb }\end{array}$ & Items & Deleted & Alpha & KMO & Factor Number \\
\hline \hline Quality & 12 & $9-28$ & $9,10,13,17,19,20,22,26$ & .890 & .901 & 1 \\
Trust & 3 & $29-31$ & - & .639 & .622 & 1 \\
Commitment & 6 & $32-34,47-48$ & 32 & .679 & .705 & 1 \\
Bonds & 5 & $36-40$ & - & .737 & .765 & 1 \\
Satisfaction & 2 & $44-45$ & - & .678 & .500 & 1 \\
Loyalty & 7 & $46,49-52$ & 52 & .515 & .602 & 1 \\
Retention & 3 & $58-60$ & - & .707 & .668 & 1 \\
\hline \hline
\end{tabular}

Therefore, prepared factors may have to be assessed in the context of research hypotheses and intergroup analysis. Descriptive statistics for the test factors were collected in the table below. They illustrate the central tendency and dispersion data.

Table -4: Descriptive Statistics for research factors

\begin{tabular}{|c|c|c|c|c|c|c|c|c|c|c|}
\hline \multirow{2}{*}{$\begin{array}{l}\text { Factor } \\
\text { Quality }\end{array}$} & \multirow{2}{*}{$\frac{N}{202}$} & \multicolumn{2}{|c|}{ Min Max M } & \multirow[b]{2}{*}{46.27} & \multirow{2}{*}{$\frac{\text { SD }}{9.21}$} & \multirow{2}{*}{$\begin{array}{l}\text { Var } \\
84.84\end{array}$} & \multicolumn{2}{|c|}{ Skew Kurt } & \multicolumn{2}{|c|}{$\mathrm{D}(\mathrm{K}-\mathrm{S}) \mathrm{D}(\mathrm{p})$} \\
\hline & & 24 & 60 & & & & -.11 & -.99 & .09 & .000 \\
\hline Trust & 202 & 4 & 15 & 11.63 & 2.55 & 6.51 & -.62 & -.26 & .13 & .000 \\
\hline Commitment & 202 & 5 & 25 & 15.96 & 3.88 & 15.05 & -.08 & -.43 & .07 & .009 \\
\hline Bonds & 202 & 8 & 25 & 18.89 & 4.08 & 16.61 & -.36 & -.58 & .09 & .001 \\
\hline Satisfaction & 202 & 2 & 10 & 7.50 & 1.97 & 3.88 & -.81 & -.08 & .21 & .000 \\
\hline Loyalty & 202 & 6 & 20 & 14.35 & 2.72 & 7.42 & -.27 & .25 & .10 & .000 \\
\hline Retention & 202 & 3 & 15 & 1.75 & 2.76 & 7.59 & -.24 & -.48 & .11 & .000 \\
\hline
\end{tabular}

6.3 Dimensions relationship and hypotheses verification

In order to verify hypotheses, the correlation analysis was performed.

Table-5: Spearman's rho correlations

\begin{tabular}{|c|c|c|c|c|c|c|}
\hline factor & Quality & Trust & Commitment & Bonds & Satisfaction & Loyalty Retention \\
\hline \multicolumn{7}{|l|}{ Quality } \\
\hline Trust & $.77^{* *}$ & & & & & \\
\hline Commitment & $.14^{*}$ & $.14^{*}$ & & & & \\
\hline Bonds & $.76^{* *}$ & $.69^{* *}$ & $.21^{* *}$ & & & \\
\hline Satisfaction & $.63^{* *}$ & $.57^{* *}$ & $.15^{*}$ & $.55^{* *}$ & & \\
\hline Loyalty & $.49^{* *}$ & $.50^{* *}$ & $.42^{* *}$ & $.51^{\star *}$ & $.39 * *$ & \\
\hline Retention & $.53^{* *}$ & $.52^{* *}$ & $.23^{* *}$ & $.51^{\star *}$ & $.38^{* *}$ & $.31^{* *}$ \\
\hline
\end{tabular}

As can be seen above all the coefficients correlate significantly. Although Commitment as a dimension indicates the least strength of the correlation coefficient, but again, the correlations are statistically significant. Other correlations can be considered as moderate or strong. What is important - all 
coefficients are positive, what indicates that the higher the results for one of the dimensions at the same time remaining increase of all others.

Table 6 Various hypotheses and their status

\begin{tabular}{|c|c|c|c|c|}
\hline No & Hypothesis & Rs & $\begin{array}{l}\text { Strengths of } \\
\text { relationship }\end{array}$ & Status \\
\hline H1 & $\begin{array}{l}\text { As bond strength rises in relationship, customer } \\
\text { trust rises simultaneously }\end{array}$ & .690 & $\begin{array}{ll}\begin{array}{l}\text { Strong } \\
\text { correlation }\end{array} & \text { positive } \\
\end{array}$ & Confirmed \\
\hline $\mathrm{H} 2$ & $\begin{array}{l}\text { As bond strength rises in relationship, customer } \\
\text { commitment rises simultaneously }\end{array}$ & .209 & $\begin{array}{l}\text { Positive correlation } \\
\text { with least strengths }\end{array}$ & Confirmed \\
\hline H3 & $\begin{array}{l}\text { As bond strength rises in relationship, customer } \\
\text { satisfaction rises simultaneously }\end{array}$ & .553 & $\begin{array}{l}\text { Strong positive } \\
\text { correlation }\end{array}$ & Confirmed \\
\hline $\mathrm{H} 4$ & $\begin{array}{l}\text { As service quality strength rises, customer trust rises } \\
\text { simultaneously }\end{array}$ & .775 & $\begin{array}{ll}\text { Strong } & \text { positive } \\
\text { correlation }\end{array}$ & Confirmed \\
\hline H5 & $\begin{array}{lccc}\text { As service quality strength } & \text { rises, customer } \\
\text { satisfaction rises simultaneously } & & \\
\end{array}$ & .631 & $\begin{array}{ll}\begin{array}{l}\text { Strong } \\
\text { correlation }\end{array} & \text { positive } \\
\end{array}$ & Confirmed \\
\hline H6 & $\begin{array}{l}\text { As trust strength rises, customer commitment rises } \\
\text { simultaneously }\end{array}$ & .136 & Weak relationship & Confirmed \\
\hline $\mathrm{H} 7$ & $\begin{array}{l}\text { As customer satisfaction strength rises, customer } \\
\text { commitment towards the store rises simultaneously }\end{array}$ & .151 & Weak relationship & Confirmed \\
\hline H8 & $\begin{array}{l}\text { As trust strength rises, customer loyalty rises } \\
\text { simultaneously }\end{array}$ & .502 & $\begin{array}{ll}\begin{array}{l}\text { Strong } \\
\text { correlation }\end{array} & \text { positive } \\
\end{array}$ & Confirmed \\
\hline H9 & $\begin{array}{l}\text { As customer commitment strength rises, customer } \\
\text { loyalty rises simultaneously }\end{array}$ & .420 & $\begin{array}{l}\text { Positive correlation } \\
\text { with least strengths }\end{array}$ & Confirmed \\
\hline H10 & $\begin{array}{l}\text { As customer satisfaction strength rises, customer } \\
\text { loyalty rises simultaneously }\end{array}$ & .393 & $\begin{array}{l}\text { Positive correlation } \\
\text { with least strengths }\end{array}$ & Confirmed \\
\hline H11 & $\begin{array}{l}\text { As customer loyalty strength rises, customer } \\
\text { retention rises simultaneously }\end{array}$ & .309 & $\begin{array}{l}\text { Positive correlation } \\
\text { with least strengths }\end{array}$ & Confirmed \\
\hline
\end{tabular}

Although test results confirmed all the hypotheses as coefficients correlated significantly, but not all correlations are same. Relations between variables are differing significantly. For example: H1, H3, H4, $\mathrm{H} 5$ and $\mathrm{H} 8$ all indicate a strong positive correlation while $\mathrm{H} 6, \mathrm{H} 7$ exhibit weak relationship. The relationships between customer commitment and customer loyalty (H9), \& Customer satisfaction and customer loyalty (H10) suggest least strengths of the relationships.

\section{Testing conceptual model: Evaluation of variables relationships}

Apart from the hypothetical relationships between variables in the form of correlations defined by mentioned hypotheses, theoretical model assumes that between research dimensions cause and effect relationships occur. For this reason, in order to assess the impact direction (cause and effect) of research variables model was analysed with using a series of regression analyses. Standardized regression coefficients that allow the assessment of the strength of the mutual influence of the variables in the model, together with statistical significance were collected in the figure below. 


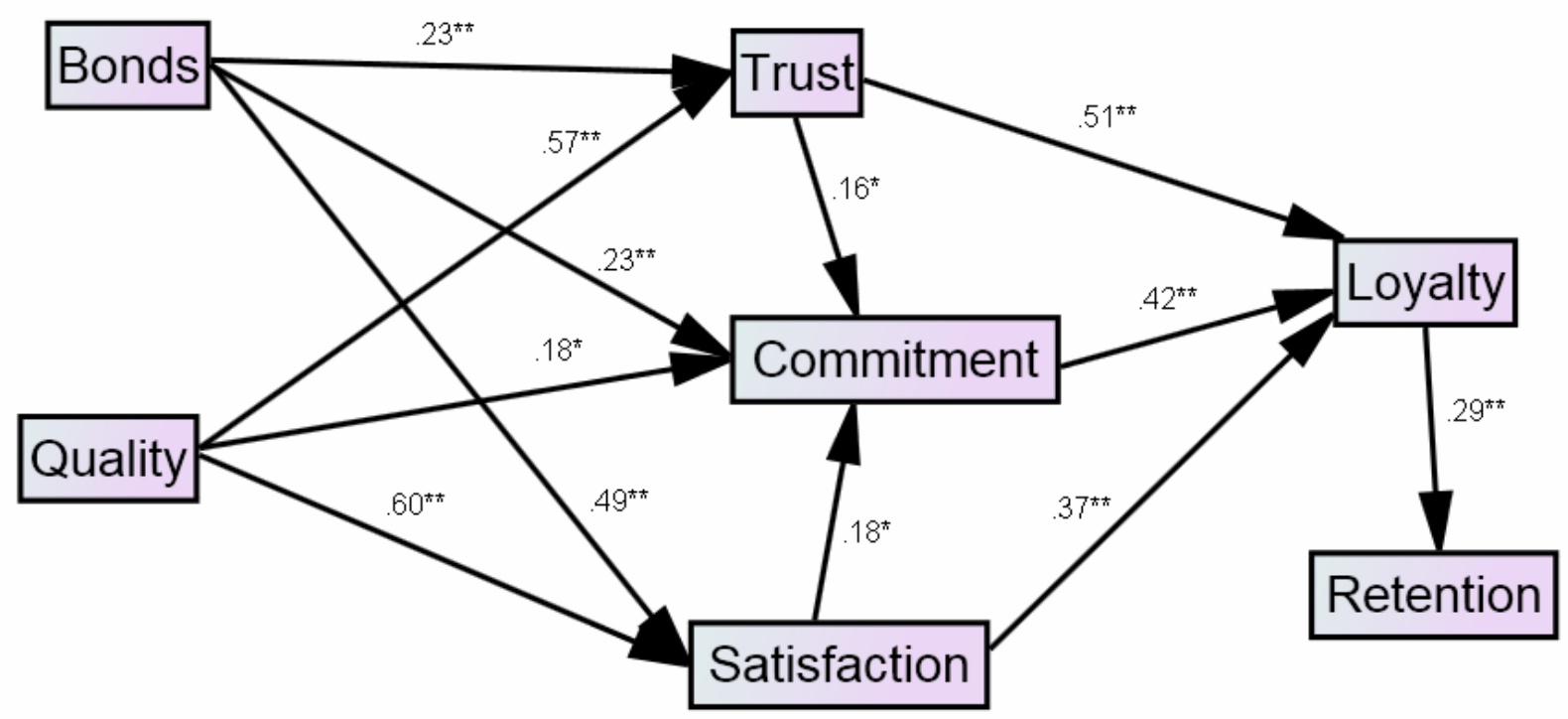

Figure 2. Customer retention strategy (CRS) model verification * $p<.05 ;{ }^{* *} p<.01$

The outcome of the analysis indicates that the various constructs in the model and their paths are statistically significant and thus validate the model. However, it is worth noting that not all "paths" have the same "power of influence". We can clearly note that Bonds stronger influence Satisfaction, than Trust or Commitment. Satisfaction and Trust are more affected by Quality than Commitment. Trust and Satisfaction are weakly related to the Commitment, although all three dimensions in a similar way comprise the Loyalty. Although the relationship between Loyalty and retention is highly statistically significant, impact strength can be considered as at best moderate.

\section{Discussions}

The hypothesized model identifies the linkages between bonds and relationships quality (H1-H3) and indicate that relationships quality (trust, commitment and satisfaction) greatly influenced by relational bonds. The findings suggest that bonds have unequal relationships with various constructs of relationships quality, but positively correlate. A very strong relationship is found between bonds and satisfaction and a weaker influence on trust and commitment. However, the relationships suggest that bond is one of the most important precursors for maximizing customer satisfaction. Hypotheses $\mathrm{H} 4$ and H5 were developed to establish the relationships between service quality and relationships quality (trust and satisfaction). The findings indicate that service quality is strongly correlated with satisfaction and trust although they do not have the same power of influence. Results indicate that service quality is strongly associated with trust and satisfaction while weakly associated with customer commitment. This is consistent with various previous studies such as Yan et al (2011); Beneke et al (2012); Al Otaibi and Yasmeen (2014).

Trust and commitment: Claycomb and Martin (2002) argue that in the service sector, because customers buy promises and not tangible goods, they must trust service providers to ensure a sustained relationship. In such instances, trust helps to build confidence, fosters cooperation, and facilitates service recovery when things go wrong in the service delivery process. Within the supermarket industry, one could argue that building a trustful relationship requires delivering core products and services efficiently and effectively in addition to ensuring honesty, reliability and integrity in dealing with customers. In contrast, transactional relationships in Bangladesh are mostly fraught with opportunistic behaviour of either the customer or the retailer and thus precluding partners' commitment. Like trust, one of the most important and central concepts for understanding the customer relationship strengths is commitment, and it is a useful construct to measure customer loyalty and predicting customer repeat purchase behavior. Various recent studies indicate that trust and commitment is positively associated, and trust is a strong predictor for commitment (Sharma et al, 2006; Cater \& Zabkar, 2008; Alrubaiee, 2012, Amani, 2015). The 
results indicate that Trust is weakly related to commitment which in contrast is not supporting previous research such as Carter \& Zabkar (2008) and Alrubaiee (2012). They have found that all three dimensions of trust (i.e integrity, competence and benevolence) positively influence commitment. Other studies also confirmed positive relationships between trust and commitment in service literature (Morgan \& Hunt, 1994, Sirdeshmukh; Singh \& Sabol, 2002).

Satisfaction and commitment: According to Heskett (2002) commitment is greatly influenced by customer satisfaction as satisfied customers are more committed towards the store. This agrees with Henning -Thurau et al (2002) who found that a high levels of customer satisfaction increases customer repeat purchase intention and has a positive impact on customer commitment. Other studies also found similar results such as Caceres and Paparoidfamis (2007), Boora and Singh (2011. These findings are not supported by the results of this study as it reveals that satisfaction is weakly related to commitment.

Results suggest that relationship quality has a positive influence on customer loyalty although with a different degree of impact for on loyalty by three constructs. These findings support previous findings of Huang (2012) that customer loyalty is positively influenced by relationship quality. The result indicates that although all three relationships quality constructs positively influence customer loyalty, but commitment correlates with least strengths of correlation coefficients. Trust has very strong positive correlation while satisfaction has least positive correlation. The findings are consistent with the previous studies. For example, Caceres \& Paparoidamis (2007) identified trust; commitment and satisfaction are three main constructs of relationship quality and empirically verified their positive effect on customer loyalty. Other studies also support that customer loyalty is strongly influenced by customer satisfaction (Sivdas and Baker-Prewit, 2000; Bloemer; Ruyter and Wetzel, 1999, Anderson \& Fornell, 1996, Sharma; Young and Wilkinson (2006); Huang (2009); Yan et al (2011) and Beneke; Hayworth; Hobson and Mia (2012).

\section{Implications: Theoretical \& Practical}

This study focused on investigating the relationship between CRM and customer retention in the food-retailing context of Bangladesh. This research is one of the few studies to examine the Bangladesh superstore-retailing context, in which organised retailing is a new phenomenon and has added new ways of the shopping experience for middle class, financially sound urban consumers. Consequently, the outcomes of this research have strong theoretical and practical implications practice to advance the potency of relationships marketing practices in Bangladesh and elsewhere with similar patterns of the retailing environment.

A) Theoretical implication

The findings of this study contribute to the body of theoretical knowledge in the following ways:

Hypothesised conceptual model: The model integrates the concept of bonds, service quality and components of relational quality (Trust, Commitment and Satisfaction) into one relationship model to demonstrate the relationship between these five constructs and customer loyalty \& retention. Hence, the theoretical implication of this model as it contributes to the body of knowledge, this model can prove beneficial to the retailers and policymakers in developing the appropriate strategies to increase customer loyalty and customer retention in a specific food retailing context.

Inclusion of CRM constructs in the conceptual model: One of the most important theoretical contribution is made by this study is the inclusion of selected and relevant constructs in the conceptual model. The findings suggest that quality of relationship is the main priority to be considered for the retail managers, not just the quality of products and services. In a Bangladesh context, the most important RM constructs are: Service quality, bonds, satisfaction, trust, commitment, loyalty and customer retention, although commitment is included in the model, it has a weaker association with loyalty.

B) Managerial implications:

Most importantly, the study empirically validated all the hypotheses and found a strong relationship between CRM and customer retention in the retail environment context of Bangladesh. Therefore, it is of paramount importance for the retailers who are hoping to retain their customers for long- term sustainability that they should unreservedly focus on sustainable customer retention strategies by incorporating important CRM constructs such as service quality, bonds, customer satisfaction, trust and loyalty. 
Demographics patterns: The findings suggest that although males are a key segment for retailers, females are also very important, as the ratio of males and females is not so wide. In Bangladesh women play a significant role as homemakers, especially in the domain of cooking and hospitality and therefore it is important that there is a cognizance of this fact. Various demographic factors reveal important aspects regarding the customer segments and a consequence must be factored into the thinking and planning of retail stores.

\section{Limitations of the Research \& direction for further studies}

The major limitations of the research are as follows:

Sampling: Most of the superstores are in the Capital City. Therefore, the study was limited due to narrow sample size, techniques and instruments. The sample of the survey was restricted to Bangladesh grocery food retailing sector. Therefore, the findings of this study are limited to the consumers of Bangladesh. Any generalisation should be made with adequate cautions; Cultural context: Consumers behave differently in different culture. Various shopping behavioural patterns are greatly influenced by people`s attitude, habits, routine, personality, beliefs, values, religion, national identity and other cultural factors (Mooij \& Hofstede, 2011). Therefore, it is important to avoid generalisation or take precautions when make any form of generalisation as the context of this study reflect the grocery food retailing sector in Bangladesh; length of the questionnaires: The questionnaires contained 70 items, a fact that could well have proved onerous for some participants and thus result in them losing concentration when answering the later questions. follows:

Based on the present study several suggestions can be drawn regarding further research as

Cultural consideration: Literature review on culture suggested that consumer shopping behaviour is greatly influenced by national culture. However, this study did not incorporate cultural dimensions in the questionnaires to understand its effect. Therefore, a cross-cultural investigation in future will be considered. Comparative study: As this is the first such study on customer retention in the Bangladesh perspective, a comparative study can be more useful to understand the statistical significance of the conceptual models and various hypotheses; Application of current conceptual model can be tested to other service industries;

\section{Conclusions}

The study focused on the concept of CRM and its relationship with customer retention. It is clear from the current literature that there are various causes and consequences of relational quality and customer retention is influenced by the relational quality (trust, commitment and satisfaction), its determinants (such as service quality and bonds) and its outcome (such as loyalty).

To understand relationships marketing and its relationships with customer retention the study developed a conceptual model by incorporating seven (7) constructs (service quality, bonds, customer satisfaction, trust, commitment, loyalty and customer retention). A total of 11 hypotheses were developed in relation to these constructs and their interrelationships. To verify these hypotheses the correlation analysis was performed by using non-parametric Spearman's rho correlation test which allows measurement of the strengths of the relationships between variables. The results confirmed all the hypotheses as the entire coefficient significantly correlate. Although degree of strengths of these relationships are not same in all cases. For example, there is a weak relationship between trust and commitment; weak relationship between bond and customer commitment; satisfaction and customer commitment. On the other hand, there is a less strengths between customer satisfaction and customer loyalty and between customer loyalty \& customer retention while strong positive correlation between service quality and customer retention; and bonds and customer trust. However, all 11 hypotheses were confirmed and accepted.

\section{References}

Adoyo, B., Charles, O.O., Patrick, B.O., Beatrice, A.O., Frederick, O.A. and Samson, N.J. (2012) 'The relationship between customer service quality and customer loyalty among retail Pharmacies in Western Kenya', Business and management Review, 2(3), pp. 11-21. 
Ahmed, R. and Buttle, F. (2001) 'Customer retention: a potentially potent marketing management strategy', Journal of Strategic Marketing, 9, pp. 29-45.

Al Otaibi, N.M. and Yasmeen, K. (2014) 'An Overview of customer loyalty, perceived service quality \& customer satisfaction: Brief on Saudi Grocery stores', Journal of Entrepreneurship E Business Innovation, 1(1), pp. 79-122.

Alrubaiee, L. (2012) 'Exploring the relationship between ethical sales behavior, relationship quality and customer loyalty', International Journal of Marketing Studies, 4(1), pp. 7-25.

Alrubaiee, L. and Al-Nazer, N. (2010) 'Investigate the Impact of Relationship Marketing Orientation on Customer Loyalty: The Customer's Perspective', International Journal of Marketing Studies, 2(1), pp. 155-174.

Anderson, E.W., Fornell, C. and Lehmann, D.R. (1994) 'Customer satisfaction, market Share and profitability: Findings from Sweden”, Journal of Marketing, 58(July), pp. 53-66.

Ang, L. and Buttle, F. (2006) 'Managing for successful customer acquisition: An exploration', Journal of Marketing Management, 22(2), pp. 295-317.

Auruskeviciene, V., Salciuviene, L. and Skudiene, V. (2010) 'The relationship quality effect on customer loyalty', Peconia, 10, pp. 23-36.

Bansal, S. and Gupta, G. (2001) 'Building Customer Loyalty Business-to-Business Commerce', in Sheth, J.N., Parvatiyar, A., and Shainesh, G. (eds.) Customer Relationship Management. New Delhi: Tata McGraw-Hill, pp. 325.

Barry, J.M. and Doney, P.M. (2011) 'Cross-cultural examination of relationship quality', Journal of Global Marketing, 24(4), pp. 305-323.

Beneke, J., Hayworth, C., Hobson, R. and Mia, Z. (2012) 'Examining the effect of retail service quality dimensions on customer satisfaction and loyalty: The case of the supermarket shopper', International Journal of Event Management Research, 5(1), pp. 27-37.

Berry, L.L. (1983) 'Relationship marketing', in Berry, L.L., Shostack, G.L., and Upah, G.D. (eds.) Emerging Perspective on Services Marketing. Chicago: American Marketing Association. pp. 25-38.

Berry, L.L. and Parasuraman, A.Q. (1991) Marketing Services. New York: The Free Press.

Bitner, M.J. (1990) 'evaluating service encounters: The effect of physical surroundings and employee responses', Journal of Marketing, 54(2), pp. 69-82.

Bitner, M.J. (1995) 'Building service relationships: it's all about promises', Journal of the Academy of Marketing Science, 23(4), pp. 246-251.

Bloemer, J., Ruyter, K.D. and Wetzel, M. (1999) 'Linking perceived service quality and service loyalty: a multidimensional perspective", European Journal of marketing, 33(11/12), pp. 1082-1106.

Boora, K.K. and Singh, H. (2011) 'Customer loyalty and its antecedents: A conceptual framework', SRI Krishna Int. Res. Educ. Consort, 2(1), pp. 151-164.

Caceres, R.C. and Paparoidamis, N.G. (2007) 'Service quality, relationship satisfaction, trust, commitment and business - to -business loyalty', European Journal of Marketing, 41(7/8), pp. 836-867.

Cann, C.W. and Sumarall, D.A. (1997) 'Services Relationship Marketing: Social Bonding in the Service Encounter', Proceedings of the annual meeting of the Southwestern Marketing Association, New Orlens, Louisiana, USA: pp. 33-38.

Cater, B. (2008) 'The Importance of Social Bonds for Communication and Trust in Marketing Relationships in Professional Services.' Management, 13, pp. 1-15.

Cater, B. and Zabkar, V. (2009) 'Antecedents and consequences of commitment in marketing research services: the client's perspective.' Industrial Marketing Management, 38, pp. 785-797.

Catherine Myhal, G., Kang, J. and Murphy, J.A. (2008) 'Retaining customers through relationship quality: A services business marketing case', Journal of Services Marketing, 22(6), pp. 445-453.

Chaudhury, A. (2003) 'the effect of affect and trust on commitment in retail store relationships.' The marketing Management Journal, 13(2), pp. 45-53.

Chen, Y.-L. And Chiu, H.-C. (2009) 'The effects of relational bonds on online customer satisfaction', The Service Industries Journal, 29(11), pp. 1581-1595.

Chiou, J.S. and Droge, C. (2006) 'Service Quality, Trust, Specific Asset Investment, and Expertise: Direct and Indirect Effects in a Satisfaction-Loyalty Framework', Journal of the Academy of Marketing Science, 34(4), pp. 613-627.

Claycomb, C. and Martin, C.L. (2002) 'Building customer relationships: an inventory of service providers' objectives and practices', Journal of Services Marketing, 16(7), pp. 615-635.

Clottey, T.A., Collier, D.A. and Stodnick, M. (2008) 'Drivers of Customer Loyalty in a Retail Store Environment', Journal of Service Science, 1(1), pp. 35-47.

Coulter, R.S. and Ligas, M. (2004) 'a typology of customer-service provider relationships: the role of relational factors in classifying customers', Journal of Services Marketing, 18(6), pp. 482-493.

Cronin, J.J. and Taylor, S.A. (1992) 'Measuring service quality: A re-examination and extension', Journal of Marketing, 56(3), pp. 55-68. 
Crosby, L.A., Evans, K.R. and Cowles, D. (1990) 'Relationship quality in service selling: An interpersonal influence perspective', Journal of Marketing, 54(July), pp. 68-81.

Dash, S., Bruning, E.D. and Guin, K.K. (2007) 'Antecedents of long-term buyer-seller relationships: a cross cultural integration', Academy of Marketing Science Review, 11, pp. 1-28.

Datta, P.R., Omar, O. and Dixon, G. (2011) 'Ralationship Marketing: Various School of Thoughts and Future Research Agenda', Presented at the International Conference on Corporate Governance \& Business Ethics, Boston, USA, 14-15th July 2011: The Business and Management Review. pp. 307-318.

Dawkins, P.M. and Reichheld, F.F. (1990) 'Customer retention as a competitive weapon', Directors and Board, 14(summer), pp. 42-47.

Dick, A.S. and Basu, K. (1994) 'Customer Loyalty: Towards and Integrated Framework', Journal of the Academy of Marketing Science, 22(2), pp. 99-113.

Dolen, W.V., Ruyter, K.D. and Lemming, J. (2004) 'An empirical assessment of the influence of customer emotions and contact employee performance on encounter and relationship satisfaction', Journal of Business research, 57(4), pp. 437-444.

Doney, P.M. and Cannon, J.P. (1997) 'An examination of the nature of trust in buyerseller relationships', Journal of Marketing, 61(2), pp. 35-51.

Dwyer, F.R., Schurr, P.H. and Oh, S. (1987) 'Developing buyer-seller relationship', The Journal of Marketing, 51(2), pp. 11-27.

Ennew, C.T. and Binks, M.R. (1996) 'The Impact of Service Quality and Service Characteristics on Customer retention: Small Businesses and their Banks in the UK', British Academy of Management, 7(3), pp. 219-230.

Erie Gonu and R. Boohene (2016), "Antecedents of Customer Retention of Ghana Commercial Bank within Agona Swedru Municipality", European Journal of Business and Management, Vol. 8 No.8

Field, A. (2005) Discovering Statistics using SPSS. 2nd edn. London, UK: Sage Publications.

Fullerton, G. (2005) 'the service quality-loyalty relationship in retail services: does commitment matter?' Journal of Retailing and Consumer Services, 12(2), pp. 99-111.

Ghahfarokhi, A.D. and Zakaria, M.S. (2009) 'The Impact of CRM on Customer Retention in Malaysia.' International Conference on Electrical Engineerring and Informatics, 5-7th August, Selangor, Malaysia.

Gilaninia, S., Almani, A.M., Pournaserani, A. and Mousavian, S.J. (2011) 'Relationship Marketing: a New Approach to Marketing in the Third Millennium', Australian Journal of Basic and Applied Sciences, 5(5), pp. 787-799.

Grewal, D., Levy, M. and Kumar, V. (2009) 'Customer experience management in retailing: An organizing framework', Journal of Retailing, 85(1), pp. 1-14.

Gronroos, C. (1994) 'From marketing mix to relationship marketing', Management Decision, 32(1), pp. 4-20.

Gronroos, C. (1996) 'Relationship Marketing Logic', Asia-Australia Marketing Journal, 4(1), pp. 7-18.

Gruen, T., summers, J. and Acito, F. (2000) 'Relationship Marketing activities, commitment and membership behaviours in professional associations', Journal of Marketing, 64(3), pp. 34-49.

Grönroos, C. (2004) 'the relationship marketing process: Communication, interaction, dialogue, value', Journal of Business and Industrial Marketing, 19(2), pp. 99-113.

Gustafsson, A., Johnson, M.D. and Roos, I. (2005) 'The Effects of Customer satisfaction, Relationship Commitment Dimensions, and Triggers on Customer Retention', Journal of Marketing, 69(October), pp. 210-218.

Hennig-Thurau, T., Gwinner, K.P. and Gremler, D.D. (2002) 'Understanding Relationship Marketing Outcomes. An Integration of Relational Benefits and Relationships Quality', Journal of Service Research, 4(3), pp. 230-247.

Hennig-Thurau, T. and Klee, A. (1997) 'the Impact of Customer Satisfaction and Relationship Quality on Customer Retention: A Critical Reassessment and Model Development', Psychology E Marketing, 14(8), pp. 737-764.

Heskett, J.L. (2002) 'Beyond Customer Loyalty', Managing Service Quality, 12(6), pp. 355-357.

Huang, C.C., Fang, S.C., Huang, S.-M., Chang, S.C. and Fang, S.R. (2014) 'the impact of relational bonds on brand loyalty: the mediating effect of brand relationship quality', Managing Service Quality, 24(2), pp. $184-204$.

Huang, C.H. (2012) 'The impact of relationship quality on customer loyalty', Journal of contemporary Management, October, pp. 53-68.

Huang, M. (2009) 'Using service quality to enhance the perceived quality of store brands', Total Quality Management $\mathcal{E}$ Business Excellence, 20(2), pp. 241-252.

Huddleston, P., Whipple, J. and VanAuken, A. (2004) 'Food Store Loyalty: Application of a Consumer Loyalty Framework', Journal of Targeting, Measurement and Analysis for Marketing, 12(3), pp. 213-230.

Hunt, S.D. (1997) 'Competing through relationships: Grounding relationship marketing in resource-advantage theory', Journal of Marketing Management, 13, pp. 431-445.

Julian, CC, Ahmed, ZU, Wel, CABC \& Bojei, J 2016, 'Discriminant analysis of antecedents of customer retention in Malaysian retailing', Journal of Transnational Management, vol. 20, no. 3, pp. 190-204.

Kim, J.O. and Jin, Y.B. (2001) 'Korean Consumers` Patronage of Discount Stores: Domestic vs. Multinational Discount Shoppers` Profiles', Journal of Consumer Marketing, 18(3), pp. 236-255. 
Kim, W.G. and Cha, Y. (2002) 'Antecedents and consequences of relationship quality in hotel industry', Hospitality Management, 21(4), pp. 321-338.

Leng, C.Y. and Botelho, D. (2010) 'How does national culture impact on consumers' decision-making styles? A cross cultural study in brazil, the United States and Japan', BAR. Brazilian Administration Review, 7(3).

Liljander, V. and Strandvik, T. (1995) 'The nature of customer relationships in services', in Swart, T.A., Bowen, D.E., and Brown, S.W. (eds.) Advances in Services Marketing and Management. London: JAI Press,

Liu, C.-T., Guo, Y.M. and Lee, C.-H. (2011) 'The effects of relationship quality and switching barriers on customer loyalty', International Journal of Information Management, 31(1), pp. 71-79.

Mahfooz, Y. (2014) 'Relationship between Service Quality and Customer Satisfaction in Hypermarkets of Saudi Arabia', International Journal of Marketing Studies, 6(4), pp. 10-22.

McGarry, E.D. (1951) 'The Contactual function in marketing', Journal of Business of the University of Chicago, 24(2), pp. 96-113.

Moeller, S., Fassnacht, M. and Ettinger, A. (2009) 'Retaining customers with shopping convenience', Journal of Relationship Marketing, 8(4), pp. 313-329.

Morgan, R.M. and Hunt, S.D. (1994) 'The commitment-trust theory of relationship marketing', Journal of Marketing, 58(3), pp. 20-38.

Mosahab, R., Mahamad, O. and Ramayah, T. (2010) 'Service quality, customer satisfaction and loyalty: a test of mediation', International Business Research, 3(4).

Murgulets, L., Eklöf, J., Dukeov, I. and Selivanova, I. (2002) 'Customer satisfaction and retention in transition economies', Total Quality Management, 12(7-8), pp. 1037-1046.

Myhal, G.C., Kang, J and Murphy, J.A. Retaining customers through relationship quality: a services business marketing case. The Journal of Services Marketing. 2008. 22 (6): 445

Nath, P. and Mukherjee, A. (2012) 'Complementary effects of relational bonds in information asymmetry contexts', Journal of Services Marketing, 26(3), pp. 168-180.

Ndubisi, N.O. (2007) 'Relationship marketing and customer loyalty', Marketing Intelligence E Planning, 25(1), pp. 98106.

Oliver, R.L. (1997) Satisfaction: A Behavioural Perspective on the Consumer. New York: McGraw-Hill.

Otaibi, D.N.M.A. and Yasmeen, K. (2014) 'An overview of customer loyalty, perceived service quality and customer satisfaction: Brief on Saudi grocery stores', Journal of Entrepreneurship and Business Innovation, 1(1), p. 79.

Padmavathy, C., Balaji, M.S. and Sivakumar, V.J. (2012) 'Measuring effectiveness of customer relationship management in Indian retail banks', International Journal of Bank Marketing, 30(4), pp. 246-266.

Palmatier, R.W., Dant, R.P., Grewal, D. and Evans, K.R. (2006) 'Factors influencing the effectiveness of relationship marketing: A Meta-Analysis', Journal of Marketing, 70(4), pp. 136-153.

Parasuraman, A., Zeithml, V.A. and Berry, L.L. (2005) 'SERVAQUAL: A multiple item scale for measuring customer perceptions of service quality", Journal of Retailing, 64(1), pp. 14-40.

Rajayogon, K. and Muthumani, S. (2015) 'The impact of demographic variables based on buying behaviour intentions towards e-store in India', Journal of theoretical and applied information Technology, 75(1), pp. 62-66.

Ranaweera, C. and Neely, A. (2003) 'Some moderating effects on the service quality-customer retention link', International Journal of Operations E Production Management, 23(2), pp. 230-248.

Reichheld, F.F. and Sasser, W.E. (1990) 'Zero defections: Quality comes to services', Harvard Business Review, 68(5), pp. 105-111.

Shamdasani, P.N. and Balakrishnan, A.A. (2000) 'Determinants of Relationship Quality and Loyalty in Personal Services', Asia Pacific Journal of Management, 17(3), pp. 399-422.

Sharma, A. and Mehta, V. (2004) 'Service quality perceptions in financial services - a case study of banking services', Journal of Services Research, 4(2), pp. 205-223.

Sharma, N., Young, L. and Wilkinson, I. (2006) 'the commitment mix: Dimensions of commitment in international trading relationships in India', Journal of International Marketing, 14(3), pp. 64-91.

Sheth, J.N. (1992) 'A Normative Model of Retaining Customer Satisfaction', Paper presented at P.D. Converse Awards Symposium, May 4-6. University of Illions, Urbana-Champaign.:

Sheth, J.N. and Parvatiyar, A. (2000) 'Evolving Relationship Marketing into a Discipline', Working paper Series, Emroy University:

Sirdeshmukh, D., Singh, J. and Sabol, B. (2002) 'Consumer trust, value, and loyalty in relational exchanges', Journal of Marketing, 66(1), pp. 15-37.

Sivadas, E. and Baker-PrewittJamieL. (2000) 'An examination of the relationship between service quality, customer satisfaction, and store loyalty', International Journal of Retail E Distribution Management, 28(2), pp. 73-82.

Sohail, S.M. (2012) 'Outsourcing the Information Technology Function: Perspectives from Employees', South African Journal of Business Management, April. 
Swaminathan, V., Page, K.L. and Gürhan-Canli, Z. (2007) “"My" brand or "Our" brand: The effects of brand relationship dimensions and Self-Construal on brand evaluations', Journal of Consumer Research, 34(2), pp. 248259.

Theodoridis, P.K. and Chatzipanagiotou, K.C. (2009) 'Store image attributes and customer satisfaction across different customer profiles within the supermarket sector in Greece', European Journal of Marketing, 43(5/6), pp. 708-734.

Wang, W., Liang, C. and Wu, Y. (2006) 'Relationship bonding tactics, relationship quality and customer behavioural loyalty-behavioural sequence in Taiwan's information service industry', Journal of Service Research, 6(1), pp. 3157.

Wilson, D.T. (1995) 'An integrated model of buyer-seller relationships', Journal of the Academy of Marketing Science, 23(4), pp. 335-345.

Wong, A. and Sohal, A. (2003) 'Service quality and customer loyalty perspectives on two levels of retail relationships', Journal of Services Marketing, 17(5), pp. 495-513.

Wong, A. and Sohal, A.S. (2006) 'Understanding the quality of relationships in consumer services', International Journal of Quality \& Reliability Management, 23(3), pp. 244-264.

Zeithaml, V.A. and Bitner, M.J. (2003) Services marketing: Integrating customer focus across the firm. 3rd edn. New York: McGraw-Hill.

Ziaullah, M., Feng, Y. and Akhter, S.N. (2014) 'Online retailing: relationship among e-tailing system quality, esatisfaction, e-trust and customers commitment in China', International Journal of Economics, Commerce and Management, 11(10), pp.1-17. 